\title{
PENGEMBANGAN MULTIMEDIA INTERAKTIF SEBAGAI MEDIA PEMBELAJARAN PADA POKOK BAHASAN DIMENSI TIGA DI SEKOLAH MENENGAH ATAS (SMA)
}

\author{
Sanusi $^{1)}$, Edy Suprapto ${ }^{2)}$, Davi Apriandi ${ }^{3)}$ \\ ${ }^{1}$ Prodi Pendidikan Matematika, FPMIPA, IKIP PGRI Madiun \\ Email: sanusihanif@yahoo.com \\ ${ }^{2}$ Prodi Pendidikan Matematika, FPMIPA, IKIP PGRI Madiun \\ Email: edypraja@gmail.com \\ ${ }^{3}$ Prodi Pendidikan Matematika, FPMIPA, IKIP PGRI Madiun \\ Email: davi_apriandi@yahoo.com
}

\begin{abstract}
Abstrak
Penelitian ini bertujuan untuk mengembangkan dan menghasilkan media pembelajaran matematika berbasis multimedia interaktif pada pokok bahasan dimensi tiga materi jarak, proyeksi dan sudut, untuk siswa SMA kelas $\mathrm{X}$ dan mengetahui bagaimanakah respon siswa setelah menggunakan media pembelajaran berbasis multimedia interaktif. Jenis penelitian ini adalah penelitian pengembangan berupa media pembelajaran berbasis multimedia interaktif pada pokok bahasan dimensi tiga materi jarak, proyeksi dan sudut. Pengembangan media mengacu pada model pengembangan ADDIE yang meliputi 5 tahap, yaitu Analysis (Analisis), Design (Perancangan), Development (Pengembangan), Implementation (Implementasi), Evaluation (Evaluasi). Subjek penelitian ini adalah 3 guru matematika SMA dan siswa kelas X SMA Negeri 1 Nglames. Instrumen yang digunakan dalam penelitian ini adalah angket pengembangan media, angket evaluasi media untuk ahli media dan ahli materi, angket evaluasi media untuk guru dan siswa, angket respon siswa, serta pedoman wawancara. Hasil penelitian pengembangan adalah: (1) Model pengembangan media pembelajaran yang dilakukan melalui beberapa tahap, yaitu melakukan analisis materi, analisis aspek-aspek yang harus ada dalam media interaktif, analisis situasi, analisis karakteristik siswa, merancang media, mengembangkan media dengan menggunakan Adobe Flash CS5, mengadakan ujicoba terbatas di SMAN 1 Nglames, mengevaluasi hasil angket. (2) Media pembelajaran mampu memberikan dampak yang positif terhadap respon siswa kelas X di SMAN 1 Nglames dengan memperoleh persentase 75,91\% dengan kriteria "tinggi".
\end{abstract}

\section{Kata Kunci: Multimedia Interaktif, Model Pengembangan ADDIE, dimensi tiga}

\section{PENDAHULUAN}

Matematika merupakan ilmu universal yang mendasari perkembangan teknologi modern dan mempunyai peranan penting dalam berbagai disiplin ilmu maupun dalam kehidupan seharihari. Berbagai masalah dalam kehidupan dapat kita pecahkan menggunakan matematika, hal tersebut dikarenakan 
hampir seluruh masalah dalam kehidupan dapat dikaitkan dengan matematika.

Matematika adalah salah satu disiplin ilmu yang mempunyai konsep yang abstrak. Berdasarkan realita yang ada, semakin abstrak konsep dalam matematika maka akan semakin menyulitkan siswa dalam memahami konsep tersebut. Salah satu aspek matematika pada satuan pendidikan SMA adalah geometri. Geometri yang secara harfiah berarti pengukuran tentang bumi adalah cabang dari matematika yang mempelajari hubungan di dalam ruang (Wikipedia, 2009). Salah satu pokok bahasan geometri yang diajarkan di Sekolah Menengah Atas (SMA) adalah dimensi tiga yaitu pada materi jarak, proyeksi dan sudut.

Dalam mempelajari pokok bahasan dimensi tiga dibutuhkan konsentrasi dan pemahaman konsep yang baik dari siswa, karena objek-objek di dalamnya bersifat abstrak. Bersifat abstrak artinya objek-objek tersebut merupakan benda-benda pikiran dimana benda-benda tersebut hanya bisa dibayangkan dalam pikiran (Anggara Rustiana B, 2008: 1). Selain itu, dalam mempelajari materi dimensi tiga membutuhkan kemampuan dalam memvisualisasikan bentuk bangun ruang. Dengan kemampuan visualisasi yang baik, diharapkan siswa dapat memahami konsep dan menyelesaikan masalah yang berkaitan dengan dimensi tiga.

Berdasarkan hasil wawancara dengan guru di salah satu Sekolah Menengah Atas (SMA) di Madiun, diperoleh informasi bahwa siswa masih mengalami kesulitan dalam menggambarkan hasil proyeksi garis terhadap garis, garis terhadap bidang maupun bidang terhadap bidang, sehingga berakibat pada kesulitan siswa dalam menyelesaikan permasalahan sudut yang dibentuk oleh beberapa kasus tersebut. Hal tersebut menunjukkan bahwa pada dasarnya siswa masih kesulitan mempelajari sesuatu yang abstrak dan akan lebih mudah dalam belajar melalui sesuatu yang bersifat konkrit. Untuk memahami konsep abstrak, siswa memerlukan benda-benda konkrit sebagai perantara atau visualisasinya. Salah satu bentuk inovasi tersebut adalah dengan penggunanan media pembelajaran berbasis multimedia interaktif.

Seiring dengan perkembangan ilmu pengetahuan dan teknologi saat ini, berbagai bentuk media pembelajaran tentu saja semakin bervariasi bentuknya, salah satu diantaranya adalah media pembelajaran yang dikembangkan melalui teknologi komputer. Menurut Azhar Arsyad (2004: 54) komputer dapat mengakomodasi siswa yang lamban 
menerima pelajaran karena ia dapat memberikan iklim yang lebih bersifat afektif dengan cara yang lebih individual dan tidak membosankan. Komputer juga dapat merangsang siswa untuk mengerjakan latihan atau simulasi karena tersedianya animasi grafik, warna dan musik yang dapat menambah realisme. sehingga dapat membantu siswa memvisualisasikan materi tentang menentukan proyeksi dan sudut dalam bangun ruang.

$$
\text { Penggunaan multimedia }
$$

interaktif dalam pembelajaran dapat memberikan dampak positif dan manfaat yang sangat luar biasa dalam memudahkan proses belajar siswa. Menurut Suyanto yang dikutip oleh Winarno (2009: 5) hasil penelitian dari Computer Technology Research (CTR) menunjukkan bahwa seseorang hanya dapat mengingat apa yang dilihatnya sebesar 20\%, 30\% dari yang didengarnya dan $80 \%$ dari yang didengar, dilihat dan dikerjakannya secara simultan. Hal ini berarti bahwa penggunaan media pembelajaran berbasis multimedia interaktif memungkinkan siswa untuk meraih hasil belajar sebesar $80 \%$ dari yang dipelajarinya.

Dari hasil pemaparan tersebut, dapat diperoleh salah satu alternatif untuk mengatasi permasalahan yang muncul, yaitu dengan mengembangkan multimedia interaktif sebagai media pembelajaran pada pokok bahasan dimensi tiga materi jarak, proyeksi dan sudut. Sasaran pengembangan media yaitu siswa SMA kelas X pada semester II.

\section{METODE PENELITIAN}

Langkah-langkah pengembangan media yang digunakan mengikuti model pengembangan ADDIE yaitu analisis, perancangan, pengembangan, implementasi, dan evaluasi. Adapun penjelasan dari masing-masing tahapan model pengembangan ADDIE adalah esbagai berikut:

1. Analisis (analysis)

Langkah ini meliputi beberapa kegiatan yaitu analisis materi, analisis aspek-aspek untuk mengembangkan media pembelajaran berbasis multimedia interaktif, analisis situasi, dan analisis karakteristik siswa,

2. Perancangan (design)

Kegiatan yang dilakukan pada tahap ini adalah menyusun story board. Storyboard merupakan visualisasi ide dari media yang akan dibuat, sehingga dapat memberikan gambaran dari media yang akan dihasilkan. Storyboard dapat dikatakan juga sebagai visual script yang akan dijadikan outline dari sebuah proyek, ditampilkan shot by shot yang biasa 
disebut dengan istilah scene (Nur Hadi Waryanto, 2005).

3. Pengembangan (development)

Pada tahap pengembangan ini, dilakukan proses pembuatan media. Kegiatan yang dilakukan meliputi mengumpulkan komponen-komponen media, pembuatan media pembelajaran interaktif, mengadakan kontrol media, selanjutnya dilakukan pengkajian media oleh ahli media dan ahli materi. Pengkajian ini dilakukan untuk memperoleh penilaian terhadap media pembelajaran interaktif, masukan dan saran untuk perbaikan dan penyempurnaan media.

4. Implementasi (implementation)

Media pembelajaran yang telah selesai dibuat, diujicobakan di tempat yang telah ditentukan yaitu di SMA Negeri 1 Nglames. Proses uji coba ini bertujuan untuk memperoleh tanggapan dari guru dan siswa mengenai media pembelajaran yang dikembangkan. Tahap ini di awali dengan penggunaan media pembelajaran interaktif oleh guru dan siswa, kemudian guru dan siswa tersebut diberi angket untuk memberikan penilaian terhadap media pembelajaran interaktif.

5. Evaluasi (evaluation)

Evaluasi yang dilakukan meliputi evaluasi media pembelajaran interaktif berdasarkan hasil angket evaluasi dan evaluasi dampak penggunaan media pembelajaran interaktif terhadap respons siswa, yang diperoleh dari angket respons siswa yang diberikan kepada siswa yang mengikuti uji coba.

Secara keseluruhan rancangan dalam pembuatan media dapat dilihat pada bagan berikut: 


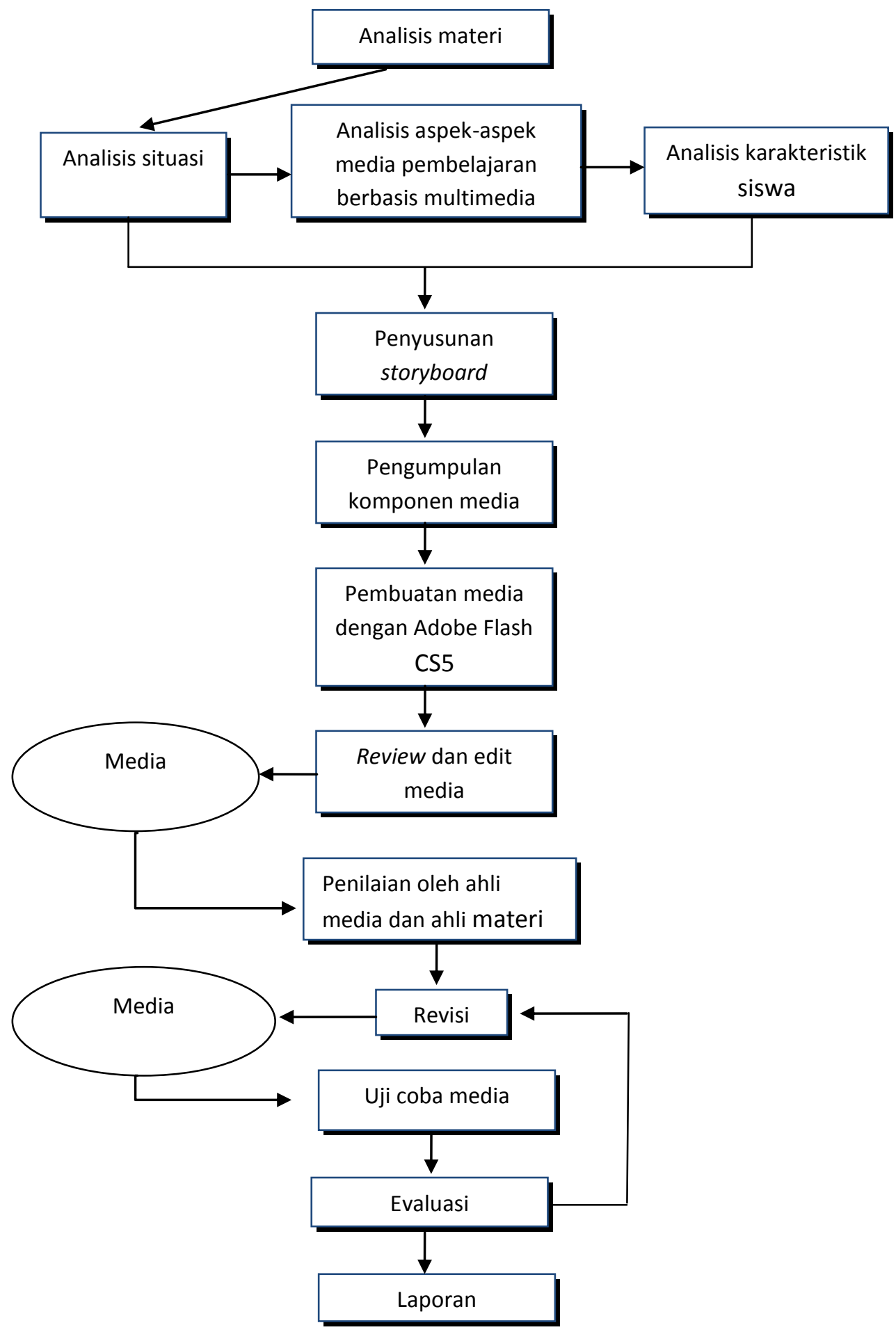

Gambar 1. Diagram Alur Rancangan Pengembangan Media

\section{HASIL PENELITIAN}

Pengembangan Media

Pembelajaran Pada Pokok Bahasan

Dimensi Tiga

1. Analysis (analisis) 
a. Analisis materi

Analisis materi dilakukan untuk menentukan materi apa yang sekiranya cocok untuk divisulisasikan dengan menggunakan media pembelajaran berbasis multimedia interaktif yang sesuai dengan kurikulum yang berlaku. Dari hasil diskusi, dipilih salah satu materi dalam mata pelajaran matematika untuk SMA yang membutuhkan visualisasi lebih banyak yaitu geometri. Selanjutnya ditetapkan pokok bahasan yang akan dibuat medianya yaitu dimensi tiga.

b. Analisis aspek-aspek yang harus ada dalam media pembelajaran berbasis multimedia interktif Aspek-aspek yang harus ada dalam media pembelajaran berbasis multimedia interaktif diperoleh dari hasil analisis angket pengembangan media yang dapat dilihat pada tabel 1 . Angket pengembangan media diisi oleh tiga guru matematika SMAN 1 Nglames. Berikut hasil angket

Tabel 1. Hasil angket pengembangan media bagian $B$

\begin{tabular}{|l|l|c|}
\hline No & \multicolumn{1}{|c|}{ Indikator } & Persentase \\
\hline 1. & $\begin{array}{l}\text { Materi harus sesuai dengan kompetensi dasar } \\
\text { dan standar kompetensi yang ingin dicapai }\end{array}$ & $100 \%$ \\
\hline 2. & Tujuan pembelajaran harus jelas & $93,33 \%$ \\
\hline 3. & Ada petunjuk penggunaan yang jelas & $100 \%$ \\
\hline 4. & Kejelasan materi & $100 \%$ \\
\hline 5. & Kebenaran konsep & $100 \%$ \\
\hline 6. & Kemudahan navigasi & $93,33 \%$ \\
\hline 7. & Kemudahan pengoperasian/penggunaan & $93,33 \%$ \\
\hline 8. & Komposisi warna tepat (tidak mencolok) & $86,67 \%$ \\
\hline 9. & Keterbacaan tulisan & $86,67 \%$ \\
\hline 10. & Bahasa yang digunakan harus mudah dipahami & $93,33 \%$ \\
\hline 11. & Animasi harus menarik & $93,33 \%$ \\
\hline 12. & Animasi dapat memperjelas materi & $93,33 \%$ \\
\hline 13. & Ada latihan soal & $100 \%$ \\
\hline 14. & Ada feed back (umpan balik) hasil latihan soal & $100 \%$ \\
\hline 15. & Dapat meningkatkan minat siswa & $100 \%$ \\
\hline 16. & Dapat membantu siswa dalam memahami materi & $100 \%$ \\
\hline
\end{tabular}

Dari hasil angket, persentase

setiap butir pernyataan lebih

dari $75 \%$, sehingga aspek-

aspek tersebut digunakan sebagai kriteria untuk membuat media pembelajaran berbasis multimedia interaktif yang baik. 
c. Analisis situasi

Hasil analisis situasi di

SMAN 1 Nglames adalah sebagai berikut :

1) Sekolah mempunyai sebuah laboratorium

komputer yang terdiri dari

56 unit komputer yang sudah terhubung LAN

(Local Area Network) dan internet. Spesifikasi komputer di laboratorium komputer SMAN 1 Nglames dapat dilihat pada tabel 2 .

Tabel 2.Spesifikasi komputer di laboratorium komputer SMAN 1

Nglames

\begin{tabular}{|l|l|}
\hline \multicolumn{1}{|c|}{ Spesifikasi Komputer } & \multicolumn{1}{c|}{ Keterangan } \\
\hline Prosesor & Intel Core i3-2100 CPU @3.10 GHz \\
\hline OS & Microsoft Windows XP SP2 \\
\hline Memori RAM & $1954 \mathrm{MB}$ \\
\hline Memori VGA & $256 \mathrm{Mb}$ \\
\hline Hardisk & $160 \mathrm{~Gb}$ \\
\hline Monitor & $15 ”$ \\
\hline CD ROM & $52 \mathrm{x}$ \\
\hline
\end{tabular}

2) Guru matematika SMAN 1

Nglames menyatakan

bahwa selama ini masih menggunakan metode ceramah, diskusi dan sesekali menggunakan LKS dalam pembelajaran matematika di kelas. Beberapa guru juga pernah menggunakan media pembelajaran matematika berbasis multimedia interaktif, tetapi media tersebut belum memenuhi kriteria media yang baik, oleh karena itu perlu dikembangkan media pembelajaran berbasis multimedia interaktif. Hasil angket pengembangan media bagian A yang disajikan pada tabel 3 .

Tabel 3. Hasil angket pengembangan media bagian A

\begin{tabular}{|l|l|l|}
\hline $\begin{array}{c}\text { No. } \\
\text { butir }\end{array}$ & \multicolumn{1}{|c|}{ Hal yang ditanyakan } & \multicolumn{1}{c|}{ Hasil } \\
\hline 1 & $\begin{array}{l}\text { Ketersediaan media pembelajaran } \\
\text { matematika berbasis multimedia } \\
\text { interaktif }\end{array}$ & $\begin{array}{l}67 \% \text { menjawab ada, tetapi } \\
\text { belum memenuhi kriteria }\end{array}$ \\
\hline 2,3 & Keterlibatan guru dalam penggunaan & 33\% pernah melihat \\
\hline
\end{tabular}




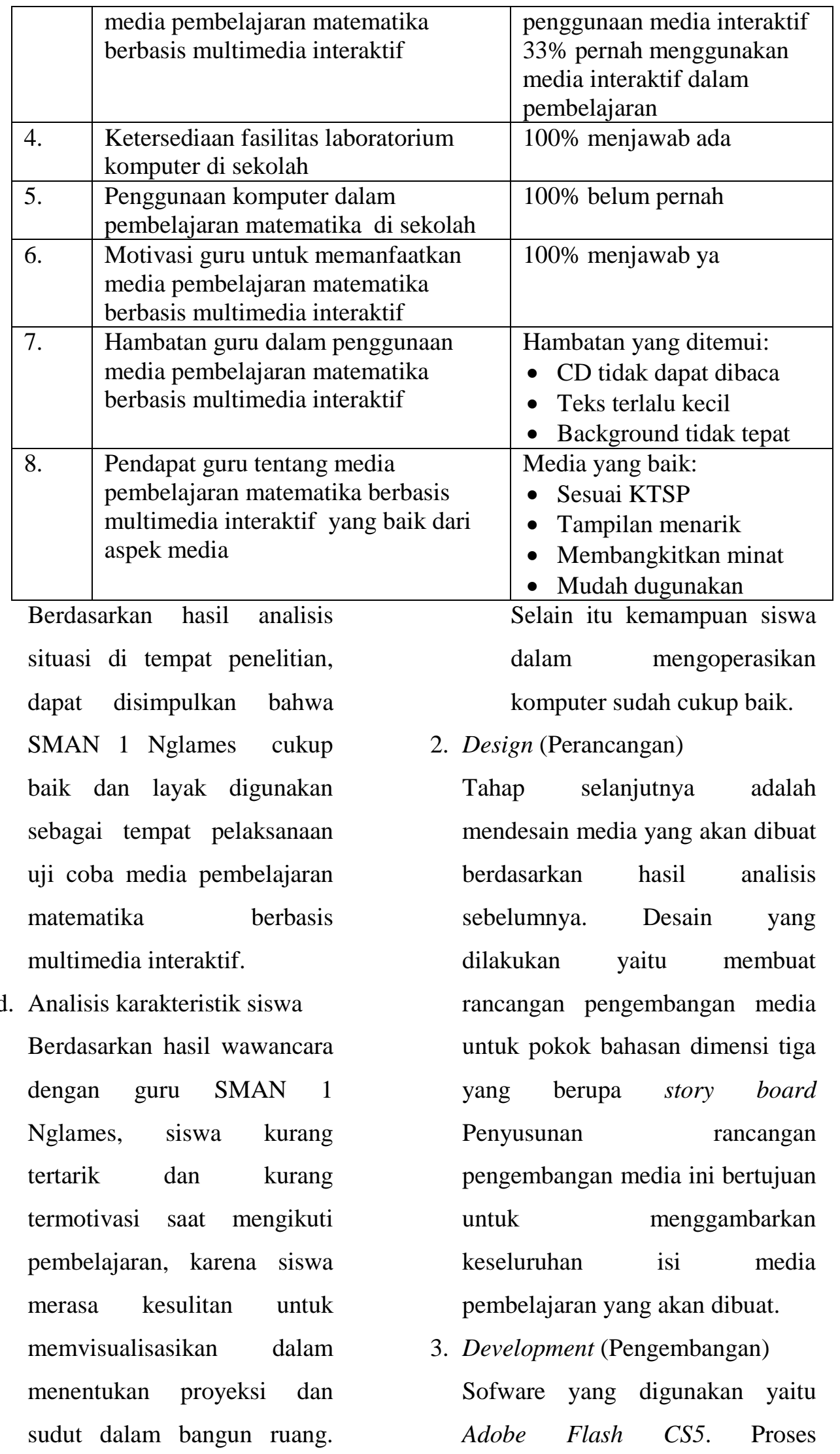


pengembangan diawali dengan

pembuatan template dan mengumpulkan komponenkomponen media, yaitu background, gambar-gambar (image), animasi, teks, simulasi, tombol navigasi, narasi serta pemilihan suara. Media pembelajaran yang akan dikembangkan ini terdiri dari intro, petunjuk dan lima pilihan menú utama, yaitu home, kompetensi, materi, evaluasi dan profil pengembang. Berikut screenshot dari media yang telah dibuat.
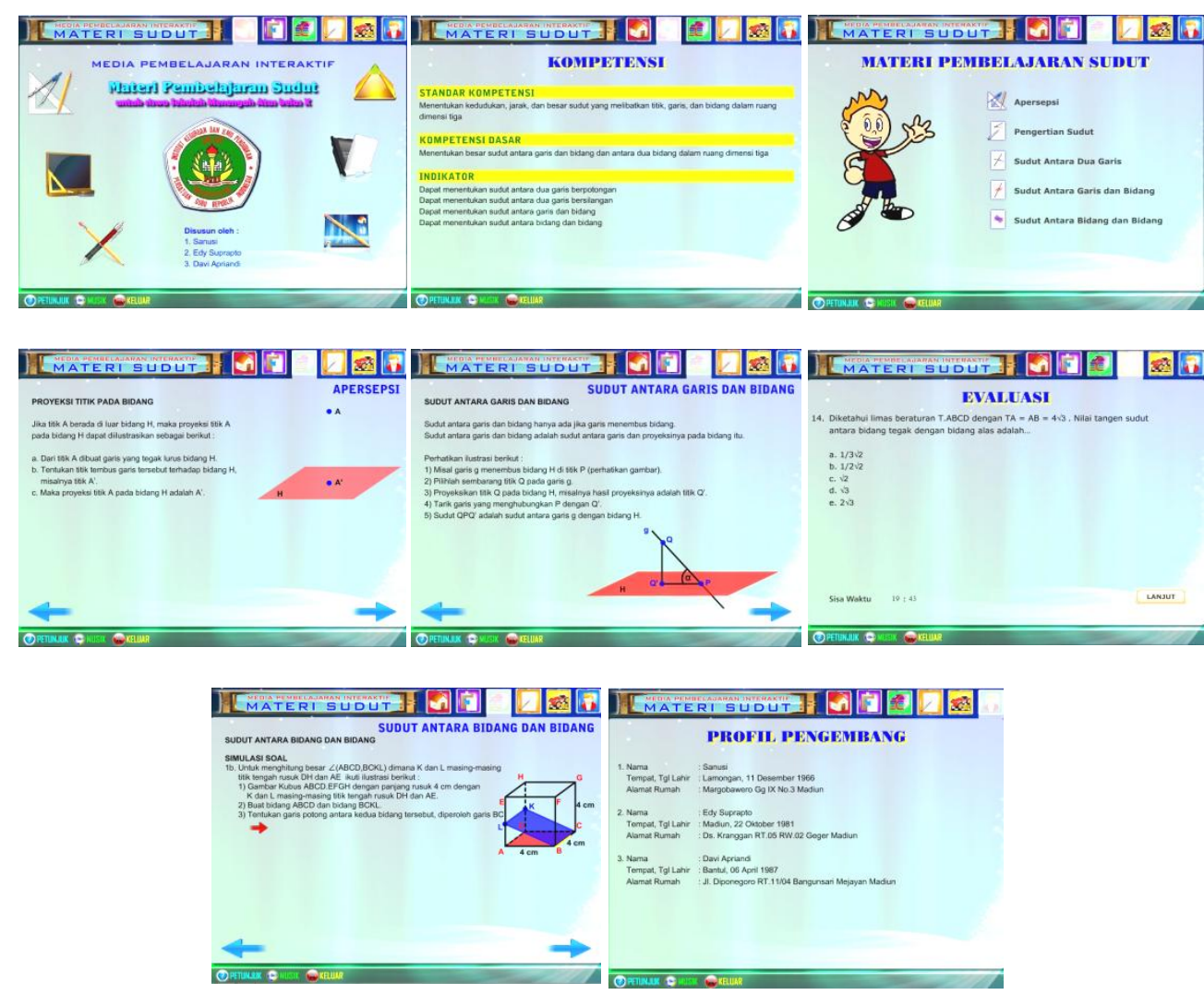

Gambar 2. Screenshot/tampilan dari media yang dikembangkan

Setelah media pembelajaran ini selesai dibuat dilakukan kontrol media, yaitu dengan mereview-edit media pembelajaran interaktif oleh pengembang, Selanjutnya dilakukan pengkajian oleh ahli media dan ahli materi. Berikut hasil evaluasi media oleh ahli media dan ahli materi. 
Tabel 4. Hasil evaluasi media oleh ahli media dan ahli materi

a. Kualitas Media

\begin{tabular}{|l|l|l|l|}
\hline No & \multicolumn{1}{|c|}{ Pernyataan } & Ahli Media & Ahli Materi \\
\hline 1. & Pemilihan warna background & Baik & Sangat baik \\
\hline 2. & $\begin{array}{l}\text { Keserasian warna background dengan } \\
\text { teks }\end{array}$ & Baik & Sangat baik \\
\hline 3. & Tata letak (layout) & Baik & Sangat baik \\
\hline 4. & Penempatan tombol dalam media & Sangat baik & Sangat baik \\
\hline 5. & Tampilan animasi & Baik & Sangat baik \\
\hline 6. & Tampilan gambar & Sangat baik & Sangat baik \\
\hline 7. & Tampilan video & Sangat baik & Baik \\
\hline 8. & Pemilihan musik pengiring media & Sangat baik & Baik \\
\hline 9. & Kejelasan narasi & Baik & Sangat baik \\
\hline 10. & Kemudahan navigasi & Sangat baik & Baik \\
\hline 11. & Ketepatan penggunaan tombol & Sangat baik & Baik \\
\hline 12. & Kemudahan memilih menu & Sangat baik & Sangat baik \\
\hline 13. & Kejelasan petunjuk pengunaan media & Baik & Baik \\
\hline 14. & Pemilihan jenis dan ukuran huruf & Baik & Baik \\
\hline 15. & Keterbacaan teks & Baik & Sangat baik \\
\hline 16. & Penggunaan bahasa yang komunikatif & Sangat baik & Sangat baik \\
\hline 17. & Kualitas simulasi & Baik & Sangat baik \\
\hline
\end{tabular}

b. Kualitas Materi

\begin{tabular}{|l|l|l|l|}
\hline No & \multicolumn{1}{|c|}{ Pernyataan } & Ahli Media & Ahli Materi \\
\hline 1. & $\begin{array}{l}\text { Kesesuaian antara kompetensi dasar, } \\
\text { indikator, tujuan, materi, dan evaluasi }\end{array}$ & Baik & Sangat baik \\
\hline 2. & Kejelasan tujuan pembelajaran & Sangat baik & Sangat baik \\
\hline 3. & Cakupan materi & Sangat baik & Sangat baik \\
\hline 4. & Keterurutan materi & Sangat baik & Sangat baik \\
\hline 5. & Keruntutan materi & Sangat baik & Sangat baik \\
\hline 6. & Kebenaran konsep & Baik & Sangat baik \\
\hline 7. & Sistematika penyajian materi & Sangat baik & Sangat baik \\
\hline 8. & Kejelasan materi & Baik & Sangat baik \\
\hline 9. & Kedalaman materi & Baik & Sangat baik \\
\hline 10. & Kemudahan memahami materi & Sangat baik & Sangat baik \\
\hline 11. & $\begin{array}{l}\text { Pemberian latihan soal untuk } \\
\text { pemahaman konsep }\end{array}$ & Baik & Baik \\
\hline 12. & $\begin{array}{l}\text { Kualitas soal-soal evaluasi dan } \\
\text { penilaiannya }\end{array}$ & Baik & Baik \\
\hline 13. & $\begin{array}{l}\text { Pemberian umpan balik terhadap latijan } \\
\text { soal dan evaluasi }\end{array}$ & Baik & Sangat baik \\
\hline 14. & $\begin{array}{l}\text { Pemberian simulasi untuk membantu } \\
\text { pemahaman konsep }\end{array}$ & Baik & Sangat baik \\
\hline 15. & $\begin{array}{l}\text { Kemungkinan meningkatkan minat } \\
\text { belajar siswa }\end{array}$ & Baik & Sangat baik \\
\hline 16. & Kemungkinan meningkatkan motivasi & Baik & Sangat baik \\
\hline
\end{tabular}




\begin{tabular}{|c|c|c|c|}
\hline & belajar siswa & & \\
\hline 17. & $\begin{array}{l}\text { Kemungkinan memberikan bantuan } \\
\text { belajar siswa }\end{array}$ & Baik & Sangat baik \\
\hline 18. & $\begin{array}{l}\text { Kemungkinan memberikan pemahaman } \\
\text { dan penguatan konsep }\end{array}$ & Baik & Sangat baik \\
\hline
\end{tabular}

Menurut dosen ahli media

kualitas media pembelajaran yang telah dibuat tergolong dalam kriteria baik. Hal ini dilihat dari hasil angket dimana setiap butir angket dikategorikan baik dan sangat baik. Dosen ahli media juga menyatakan bahwa media pembelajaran hasil pengembangan layak untuk diuji cobakan di lapangan dengan revisi sesuai dengan masukan dan saran dari dosen ahli media. Adapun beberapa masukan dan saran dari dosen ahli media yaitu:

1) Setiap langkah dalam bagian simulasi sebaiknya diikuti dengan animasi pada bangun ruang

2) Dalam satu layar masih terlalu banyak tulisan, seperti pada bagian petunjuk, teks petunjuk perlu dipersingkat lagi.

3) Ukuran huruf pada bagian kompetensi diperbesar agar sesuai dengan layar

4) Warna huruf sebaiknya dibuat lebih menarik, tidak semua hitam
5) Tombol untuk kembali ke materi awal tidak berfungsi

6) Kalimat soal pada latihan soal perlu diperhatikan lagi

Menurut dosen ahli materi, kualitas media pembelajaran matematika berbasis multimedia interaktif pada pokok bahasan dimensi tiga hasil pengembangan tergolong dalam kriteria baik. Dosen ahli materi menyatakan bahwa media pembelajaran matematika berbasis multimedia interaktif hasil pengembangan layak untuk diujicobakan di lapangan dengan revisi sesuai dengan saran dari dosen ahli materi pembelajaran.Berikut masukan dan saran dari ahli materi.

1) Ada kesalahan pada bagian simulasi untuk sub bab sudut antara garis dan bidang

2) Tombol menuju ke soal berikutnya dan sebelumnya pada latihan soal perlu difungsikan

3) Tombol untuk kembali ke materi awal tidak berfungsi 
Secara keseluruhan penilaian ahli media dan ahli materi, media yang dikembangkan sudah baik dan layak di uji cobakan dalam pembelajaran matematika

Setelah dilakukan revisi di beberapa bagian dihasilkan media pembelajaran matematika berbasis multimedia interaktif yang sudah dapat diuji cobakan. Selanjutnya adalah pengemasan media pembelajaran berbasis multimedia interaktif yang sudah selesai dibuat ke dalam bentuk compact disc (CD) sehingga penggunaannya dapat fleksibel.

\section{Implementation (Implementasi)}

Pada tahap ini dilakukan uji coba media kepada guru matematika dan siswa SMA N 1 Nglames kelas X. Pelaksanakan uji coba media pembelajaran matematika berbasis multimedia interaktif sebagai berikut:

a. Menjelaskan kepada siswa tata cara menggunakan media pembelajaran matematika berbasis multimedia interaktif

b. Mempersilahkan siswa belajar menggunakan media pembelajaran matematika berbasis multimedia interaktif yang telah diinstal dalam komputer selama 60 menit

c. Membagikan lembar evaluasi media dan angket respons siswa, lalu meminta siswa untuk mengisinya.

Dalam pelaksanaan uji coba media pembelajaran matematika berbasis multimedia interaktif mengalami beberapa keterbatasan, antara lain:

a. Pada saat pembelajaran ada beberapa siswa yang membuka situs ataupun program komputer yang lainnya sehingga konsentrasi mereka terpecah

b. Komputer yang tersedia tidak dilengkapi dengan speaker, hanya komputer untuk guru yang tersedia speaker. Dengan hanya ada satu speaker ini setidaknya dapat membantu siswa mendengarkan sound musik dalam media.

\section{Evaluation (Evaluasi)}

Tahap terakhir adalah mengevaluasi media pembelajaran matematika berbasis multimedia interaktif yang telah dikembangkan berdasarkan hasil angket yang telah diperoleh dari tahap implementasi. 
a. Evaluasi media oleh guru

evaluasi media untuk guru. matematika

Ada tiga guru Hasil evaluasi terhadap media matematika SMAN 1 Nglames yang melakukan uji pembelajaran interaktif dari ketiga guru tersebut dapat coba dan mengisi angket dilihat pada tabel berikut ini.

Tabel 5. Hasil evaluasi media pembelajaran matematika berbasis multimedia interaktif oleh guru

\begin{tabular}{|l|l|c|}
\hline \multirow{2}{*}{ No. } & \multicolumn{1}{|c|}{ Pernyataan } & \multirow{2}{*}{ Persentase } \\
\cline { 2 - 3 } & \multicolumn{1}{|c|}{ Kualitas isi dan tujuan pembelajaran } \\
\hline 1. & $\begin{array}{l}\text { Kesesuaian antara kompetensi dasar, indikator, tujuan, } \\
\text { materi, dan evaluasi }\end{array}$ & $91.67 \%$ \\
\hline 2. & Kejelasan tujuan pembelajaran & $83.33 \%$ \\
\hline 3. & Cakupan materi & $83.33 \%$ \\
\hline 4 & Keterurutan materi & $83.33 \%$ \\
\hline 5. & Keruntutan materi & $91.67 \%$ \\
\hline 6. & Kebenaran konsep & $83.33 \%$ \\
\hline 7. & Sistematika penyajian materi & $100.00 \%$ \\
\hline 8. & Kejelasan materi & $91.67 \%$ \\
\hline 9. & Kedalaman materi & $91.67 \%$ \\
\hline 10. & Kemudahan memahami materi & $91.67 \%$ \\
\hline 11. & Pemberian latihan soal untuk pemahaman konsep & $91.67 \%$ \\
\hline 12. & Kualitas soal-soal evaluasi dan penilaiannya & $91.67 \%$ \\
\hline 13. & Pemberian umpan balik terhadap latihan soal dan & $83.33 \%$ \\
\hline 14. & evaluasi & $\begin{array}{l}|c| \\
\text { kemberian simulasi untuk membantu pemahaman }\end{array}$ \\
\hline & & $91.67 \%$ \\
\hline 15. & Pemilihan warna background & $83.33 \%$ \\
\hline 16. & Keserasian warna background dengan teks & $83.33 \%$ \\
\hline 17. & Tata letak (layout) & $100.00 \%$ \\
\hline 18. & Penempatan tombol dalam media & $91.67 \%$ \\
\hline 19. & Tampilan animasi & $91.67 \%$ \\
\hline 20. & Tampilan gambar & $91.67 \%$ \\
\hline 21. & Tampilan video & $91.67 \%$ \\
\hline 22. & Pemilihan musik pengiring media & $75.00 \%$ \\
\hline 23. & Kejelasan narasi & $83.33 \%$ \\
\hline 24. & Kemudahan navigasi & $91.67 \%$ \\
\hline 25. & Ketepatan penggunaan tombol & $75.00 \%$ \\
\hline 26. & Kemudahan memilih menu & $83.33 \%$ \\
\hline 27. & Kejelasan petunjuk pengunaan media & $83.33 \%$ \\
\hline 28. & Pemilihan jenis dan ukuran huruf & $83.33 \%$ \\
\hline 29. & Keterbacaan teks & $91.67 \%$ \\
\hline 30. & Penggunaan bahasa yang komunikatif & $91.67 \%$ \\
\hline 31. & Kualitas simulasi & $83.33 \%$ \\
\hline & & $91.67 \%$ \\
\hline
\end{tabular}




\begin{tabular}{|l|l|c|}
\hline & \multicolumn{1}{|c|}{ Kualitas intruksional } & $91.67 \%$ \\
\hline 32. & Kemungkinan meningkatkan minat belajar siswa & $100.00 \%$ \\
\hline 33. & Kemungkinan meningkatkan motivasi belajar siswa & $91.67 \%$ \\
\hline 34. & Kemungkinan memberikan bantuan belajar siswa & $91.67 \%$ \\
\hline 35. & $\begin{array}{l}\text { Kemungkinan memberikan pemahaman dan penguatan } \\
\text { konsep }\end{array}$ & $83.33 \%$ \\
\hline
\end{tabular}

Menurut ketiga guru

matematika SMAN 1

Nglames, media pembelajaran sudah cukup baik. Hal ini dilihat dari hasil evaluasi angket yang telah diisi oleh ketiga guru matematika, tidak ada butir yang persentasenya kurang dari $75 \%$, sehingga tidak ada yang perlu direvisi untuk setiap butir. Ketiga guru tersebut juga memberikan masukan dan saran untuk media pembelajaran matematika ini. Adapun masukan dan sarannya adalah sebagai berikut:

1) Kesalahan dalam penulisan rumus luas juring lingkaran pada bagian luas permukaan kerucut.

2) Narasi perlu variatif agar siswa lebih tertarik dan tidak bosan.

3) Narasi kurang jelas, kadang tertutup dengan musik.
4) Kalimat soal pada latihan soal perlu diperjelas lagi maksudnya.

5) Soal-soal pada bagian evaluasi lebih variatif, tidah hanya pemahaman konsep, tetapi pemecahan masalah, penalaran dan komunikasi.

6) Pemilihan warna lebih menggunakan warna yang cerah agar menarik perhatian siswa

Selain data dari angket, peneliti juga melakukan wawancara dengan salah satu guru. Dari hasil wawancara secara keseluruhan, media pembelajaran interaktif yang telah dikembangkan sudah baik, jelas, menarik, dan dapat menambah minat dan motivasi siswa dalam belajar matematika. Media pembelajaran interaktif ini dikembangkan untuk siswa SMA pada umumnya sehingga dapat digunakan oleh guru matematika untuk mengajar. 
b. Evaluasi media oleh siswa

Tabel 6. Hasil evaluasi media pembelajaran matematika berbasis multimedia interaktif oleh siswa

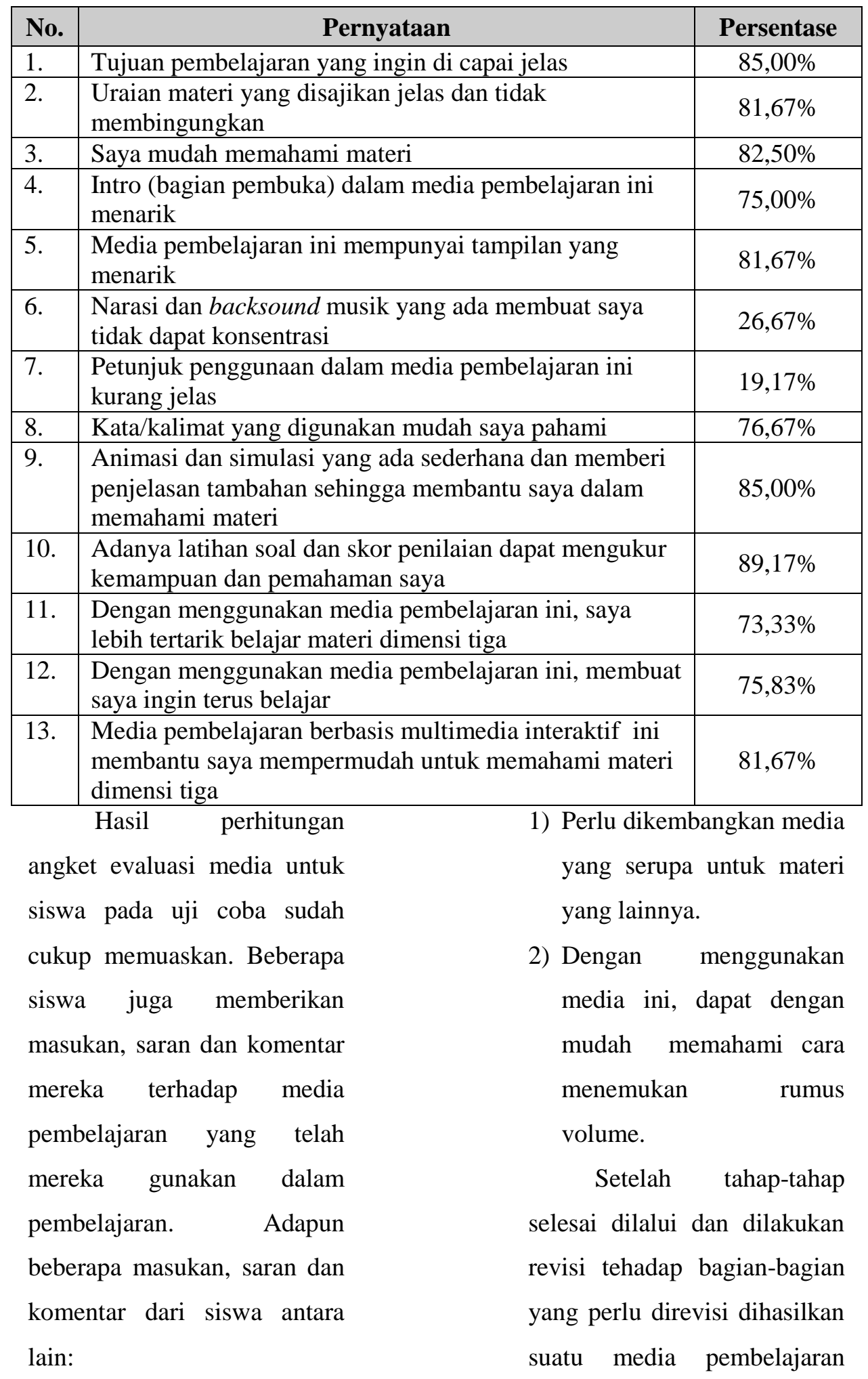




matematika berbasis
multimedia interaktif pada
pokok bahasan dimensi tiga
yang diharapkan dapat
membantu siswa dalam
memahami materi dimensi
tiga.

Respons Siswa Terhadap Penggunaan Media Pembelajaran

\begin{tabular}{llr}
\multicolumn{1}{c}{ Angket } & respons & siswa \\
diberikan & setelah & siswa \\
menggunakan & media & pembelajaran \\
berbasis multimedia interaktif pada
\end{tabular}

pokok bahasan dimensi tiga. Dari lembar angket respons siswa yang diberikan kepada siswa diperoleh data tentang respons siswa terhadap media yang dimaksud. Hasil skor tiap butir pernyataan angket respons siswa dipersentase dan dikualifikasi untuk mengetahui respons siswa setelah menggunakan media pembelajaran interaktif yang telah dikembangkan. Berikut ini hasil perhitungan angket respons siswa (ditinjau dari tiap butir pernyataan).

Tabel 7. Hasil analisis angket respons siswa

\begin{tabular}{|l|l|c|c|c|}
\hline No & \multicolumn{1}{|c|}{ Pernyataan } & $\begin{array}{c}\text { Jumlah } \\
\text { Skor }\end{array}$ & Prsntase & Kriteria \\
\hline 1. & $\begin{array}{l}\text { Saya merasa senang mengikuti } \\
\text { pembelajaran materi dimensi tiga yang } \\
\text { menggunakan media pembelajaran } \\
\text { tersebut }\end{array}$ & 92 & $76,67 \%$ & Tinggi \\
\hline 2. & $\begin{array}{l}\text { Menurut saya, pembelajaran materi } \\
\text { dimensi tiga dengan menggunakan } \\
\text { media pembelajaran tersebut menjadi } \\
\text { lebih menyenangkan, tidak } \\
\text { menimbulkan kebosanan }\end{array}$ & 100 & $83,33 \%$ & $\begin{array}{l}\text { Sangat } \\
\text { tinggi }\end{array}$ \\
\hline 3. & $\begin{array}{l}\text { Media pembelajaran tersebut sangat } \\
\text { menarik bagi saya sehingga saya } \\
\text { menjadi lebih bersemangat dalam } \\
\text { belajar materi dimensi tiga }\end{array}$ & 86 & $71,67 \%$ & Tinggi \\
\hline 4. & $\begin{array}{l}\text { Saya berusaha mengikuti pembelajaran } \\
\text { materi dimensi tiga yang menggunakan } \\
\text { media pembelajaran tersebut hingga } \\
\text { selesai }\end{array}$ & 94 & $78,33 \%$ & Tinggi \\
\hline 5. & $\begin{array}{l}\text { Dengan senang hati, saya melakukan } \\
\text { aktivitas-aktivitas belajar dengan } \\
\text { menggunakan media pembelajaran } \\
\text { tersebut }\end{array}$ & 85 & $70,83 \%$ & Tinggi \\
\hline 6. & $\begin{array}{l}\text { Saya ingin melakukan seluruh } \\
\text { aktivitas-aktivitas belajar dengan } \\
\text { menggunakan media pembelajaran } \\
\text { tersebut }\end{array}$ & 85 & $70,83 \%$ & Tinggi \\
\hline
\end{tabular}




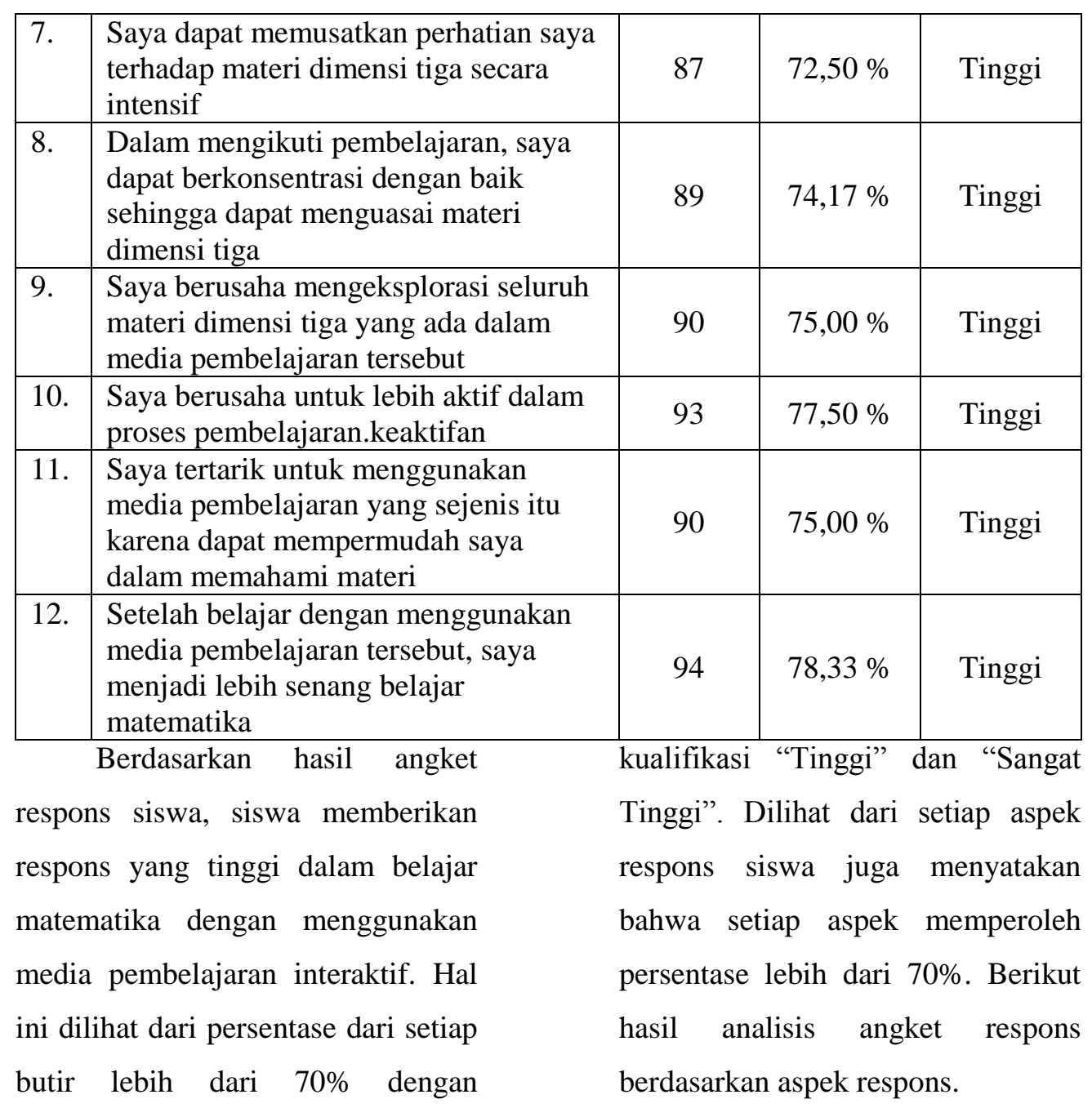

Tabel 8. Hasil Analisis Angket Respons Siswa Berdasarkan Aspek Respons

\begin{tabular}{|l|c|c|c|}
\hline \multicolumn{1}{|c|}{ Aspek } & Jumlah Skor & Persentase & Kriteria \\
\hline Rasa Senang $(1,2,12)$ & 286 & $79,44 \%$ & Tinggi \\
\hline Semangat $(3)$ & 86 & $71,67 \%$ & Tinggi \\
\hline Keingintahuan $(4,9)$ & 184 & $76,67 \%$ & Tinggi \\
\hline Keaktifan $(5,6,10)$ & 263 & $73,06 \%$ & Tinggi \\
\hline Perhatian $(7,8)$ & 176 & $73,33 \%$ & Tinggi \\
\hline Ketertarikan (11) & 90 & $75,00 \%$ & Tinggi \\
\hline \multicolumn{2}{|c|}{ Selanjutnya peneliti meninjau siperoleh masing-masing siswa }
\end{tabular}

dampak penggunaan media dalam mengisi angket respons siswa. pembelajaran interaktif terhadap Berikut perhitungan dalam respons siswa secara klasikal. Hal memperoleh persentase respons ini dapat dilihat dari skor yang siswa.

Skor maksimal yang mungkin dicapai $=\sum$ butir $\mathrm{x} \sum$ siswa $\mathrm{x} 4$

$$
=12 \times 30 \times 4
$$




$$
\begin{aligned}
& =1440 \\
\text { Persentase respons siswa } & =\frac{\text { skor total }}{\text { skor maksimal }} \times 100 \% \\
& =\frac{1100}{1440} \times 100 \% \\
& =75,35 \%
\end{aligned}
$$

Dari data angket respons

2. Respons siswa setelah siswa diperoleh persentase respons siswa sebesar 75,35\%. Hal ini menunjukkan bahwa setelah belajar dengan menggunakan media pembelajaran interaktif, respons siswa untuk belajar matematika termasuk dalam kualifikasi "Tinggi" (Suharsimi Arikunto, 2007: 18-19). Jadi secara keseluruhan, respons siswa setelah menggunakan media pembelajaran matematika berbasis multimedia interaktif pada pokok bahasan dimensi tiga sudah baik.

\section{KESIMPULAN}

Berdasarkan hasil penelitian dan pembahasan maka dapat diambil kesimpulan sebagai berikut:

$\begin{array}{lr}\text { 1. Pengembangan } & \text { media } \\ \text { pembelajaran } & \text { berbasis } \\ \text { multimedia interaktif pada pokok } \\ \text { bahasan dimensi tiga untuk siswa } \\ \text { SMA kelas X meliputi } 5 \text { tahap } \\ \text { yaitu Analisis (analysis), } \\ \text { Perancangan } \quad \text { (design), } \\ \text { Pengembangan (development), } \\ \text { Implementasi (implementation), } \\ \text { Evaluasi (evaluation). }\end{array}$
menggunakan media pembelajaran matematika berbasis multimedia interaktif yang telah dikembangkan sudah baik. Hal ini terlihat dari:

a. Persentase respons siswa pada tiap butir pernyataan angket respons menunjukkan persentase di atas $70 \%$, dengan kualifikasi "Tinggi" dan "Sangat Tinggi".

b. Persentase setiap aspek respons siswa juga menyatakan bahwa setiap aspek memperoleh persentase lebih dari $70 \%$. Persentase skor rata-rata tiap aspek respons siswa, yaitu:

1) Rasa senang sebesar $79,44 \%$ dengan kriteria tinggi.

2) Semangat sebesar $71,67 \%$ dengan kriteria tinggi.

3) Keingintahuan sebesar $76,67 \%$ dengan kriteria tinggi. 
4) Keaktifan sebesar $73,06 \%$ dengan kriteria tinggi.

5) Perhatian sebesar $73,33 \%$ dengan kriteria tinggi.

6) Ketertarikan sebesar $75,00 \%$ dengan kriteria tinggi.

Persentase respons siswa secara klasikal sebesar $75,35 \%$, dengan dengan kualifikasi tinggi.

\section{DAFTAR PUSTAKA}

Anggara Rustiana B. 2008. Diktat Belajar Mahasiswa Mata Kuliah Geometri.

Azhar Arsyad. 2004. Media Pembelajaran. Jakarta: Raja Grafindo Persada

Nur Hadi Waryanto. 2005. Storyboard Dalam Media Pembelajaran Interaktif. Disajikan di http://staff.uny.ac.id/sites/defa ult/files/tmp/ Storyboard\%20 dalam\%20Media\%20Pembela jaran\%20Interaktif.pdf.

Diunduh tanggal 22 Pebruari 2013.
Suharsimi Arikunto. 2007. DasarDasar Evaluasi Pendidikan. Jakarta: Bumi Aksara.

Winarno, dkk. 2009. Teknik Evaluasi Multimedia Pembelajaran. Genius Prima Media.

Wikipedia. 2009. Geometri. Disajikan di http://id.wikipedia.org/wiki/G eometri. Diunduh tanggal 10 Januari 2013. 